\title{
Analysis of the Discriminatory Perceptions of Victims on Damage from Environmental Pollution: A Case Study of the Hebei Spirit Oil Spill in South Korea
}

\author{
Jae-Hyuck Lee (1) and Do-Kyun Kim * \\ Sustainability Strategy Research Group, Division of Social Environment, Korea Environment Institute, \\ Sejong 30147, Korea; jaehyuck@kei.re.kr \\ * Correspondence: dkkim@kei.re.kr; Tel.: +82-44-415-7438
}

check for

updates

Citation: Lee, J.-H.; Kim, D.-K. Analysis of the Discriminatory Perceptions of Victims on Damage from Environmental Pollution: A Case Study of the Hebei Spirit Oil Spill in South Korea. Land 2021, 10, 1089. https://doi.org/10.3390/ land10101089

Academic Editors: Moira Zellner and Juan Carlos Castilla-Rho

Received: 16 July 2021

Accepted: 13 October 2021

Published: 15 October 2021

Publisher's Note: MDPI stays neutral with regard to jurisdictional claims in published maps and institutional affiliations.

Copyright: (c) 2021 by the authors. Licensee MDPI, Basel, Switzerland. This article is an open access article distributed under the terms and conditions of the Creative Commons Attribution (CC BY) license (https:// creativecommons.org/licenses/by/ $4.0 /)$.

\begin{abstract}
Environmental pollution causes severe damage to local communities, which is perceived differently by different victims, that is, the damage is discriminatory. However, previous studies have not focused on this aspect. Here, we explored the perceptions of different victims of the Hebei Spirit oil spill incident of Korea. Additionally, we explored the importance of considering discriminatory aspects of damage when planning recovery governance. The damages from the oil spill were analyzed using a text mining technique for each subject based on factor analyses. Women and residents older than 60 years were interested in the social relations of the village community; residents in their 40s, who were raising children and teenagers, were interested in the economic aspects; boat fishermen, who had discontinued fishing to participate in the pollution response activity in the early stages of the incident, were interested in disaster prevention; and women divers were interested in health issues. Hence, restoring the economy and environment and reversing indirect social damages are essential for recovery from pollution damage. Furthermore, governance for recovery must not exclude specific victims based on the discriminatory aspects of damages. A political process is necessary to secure the validity of governance and alternatives by involving different victim groups.
\end{abstract}

Keywords: environmental pollution; Hebei Spirit oil spill; pollution damage; local fishing communities; damage recovery; discriminatory aspects

\section{Introduction}

Industrialization has resulted in unparalleled exponential economic prosperity. However, it has also led to small- and large-scale environmental pollution incidents, which have caused biophysical damages to the environment, and fatal damages to humans and society, including irreversible damages to physical health, contractions in economic activities, social conflict, and psychological stress [1-3]. These consequences affect the victims of environmental pollution differently according to their socioeconomic conditions $[4,5]$. Differences in the degree of damage to work and health undermine the relationships among community members and may cause conflicts [6,7]. Therefore, the different detrimental effects of environmental pollution on stakeholders should be investigated [8,9].

Identifying the types of discriminatory damages affecting victims is essential not only for comprehensively understanding the social impact of environmental pollution incidents on humans, but also for developing policies for post-disaster recovery. However, the majority of previous studies have focused only on the participation and cooperation of victims [10-12], failing to expand their research scope to include the types of damages experienced by different people and how different perceptions of damage affect the recovery process. Damage from environmental pollution reinforces pre-existing inequality [13] as it can tremendously affect socially weak people, who require more time for recovery. Thus, damage is discriminatory depending on the socioeconomic conditions of the victims. The 
recovery approach focuses on the majority of the population, creating inequalities among minorities, thus leading to local conflicts [14].

Within this context, the purpose of this study was to analyze the different perceptions of damage among victims of a large-scale marine oil spill incident that occurred in the west sea of Korea in December 2008. Perceptions of damage were analyzed through the text mining of victim interviews to identify potential recovery measures and governance suggestions. The communities living near the location of the incident suffered severe damages from the marine pollution as they were highly dependent on marine resources [15], resulting in various damages to the fishery and tourism industries, and conflicts in the process of compensation. The fishing village of Sowon-myeon (Chungcheongnam-do), which is located near the oil spill site, suffered the most severe damages [16]. We examined the different aspects of the damages using transcripts of in-depth interviews conducted with the residents of Sowon-myeon. The text mining technique used was based on factor analysis and was used to analyze the transcripts of each victim to identify the characteristics of each stakeholder [17]. Through this technique, we aimed to identify stakeholders with different victim characteristics, and to suggest ways to pace the post-disaster recovery process with their cooperation and strong policy modifications based on the perceptions of victims.

\section{Materials and Methods}

\subsection{Study Sites}

On 7 December 2007, a Hong Kong-registered crude oil tanker, Hebei Spirit (146,848 tons), collided with a crane barge owned by Samsung Heavy Industries (11,828 tons) off the coast of Taean-gun, spilling oil that spread 12,547 kilometers into the sea [18-22]. The oil spill caused severe environmental pollution in the coastal waters of Taean-gun, on the west coast of Korea. In particular, the Sowon-myeon area close to the accident site suffered the most serious damage. The peninsula region is famous for various primeval fishing and tourism businesses.

The study sites (Figure 1) included three fishing villages: Uihang, Mohang, and Gauido. The wide tidal flats on the east coast of Uihang supported the development of shellfish hand-fishing, such as oysters and clams. The majority of the residents depend on hand fishing for their livelihoods as boat fishing has been developed on a smaller scale. In contrast, small tidal flats occur in Mohang, and boat fishing has been developed near the port. Thus, Mohang is one of the representative boat fishing areas in the northern region of Taean. Additionally, multiple Korean fisherwomen called haenyeos live near the port. Gauido is an island village located $5 \mathrm{~km}$ away from the coast. Despite the absence of tidal flats or ports, the village depends on the hand fishing of seaweed, such as sea mustard on coastal rocks. Tidal flats and coastal rocks, which are major fishing grounds for Uihang and Gauido residents, serve as common resources shared among the neighboring residents. As these regions are located near the oil spill site, residents of the three villages suffered severe environmental damages resulting from oil reaching the coastline, and multiple social disasters due to the disruption of traditional economic activities that depended on marine resources [15].

\subsection{Research Methodology}

In-depth interviews with residents belonging to the three fishing villages and with different socioeconomic backgrounds were conducted to explore the discriminatory aspects of damages caused by the Hebei Spirit oil spill. Subsequently, transcripts were analyzed using text mining to understand the victim characteristics of each stakeholder. Previous text mining analyses have either focused on analyzing interviewees' opinions as one [23,24], or on investigating only the socioeconomic conditions of the stakeholders previously classified by the researcher $[25,26]$. However, these analysis techniques were limited as the opinions of minorities, who were not selected by the researchers, were not revealed. Thus, in this study, text mining was used for each subject to analyze the words commonly used by each victim group. 


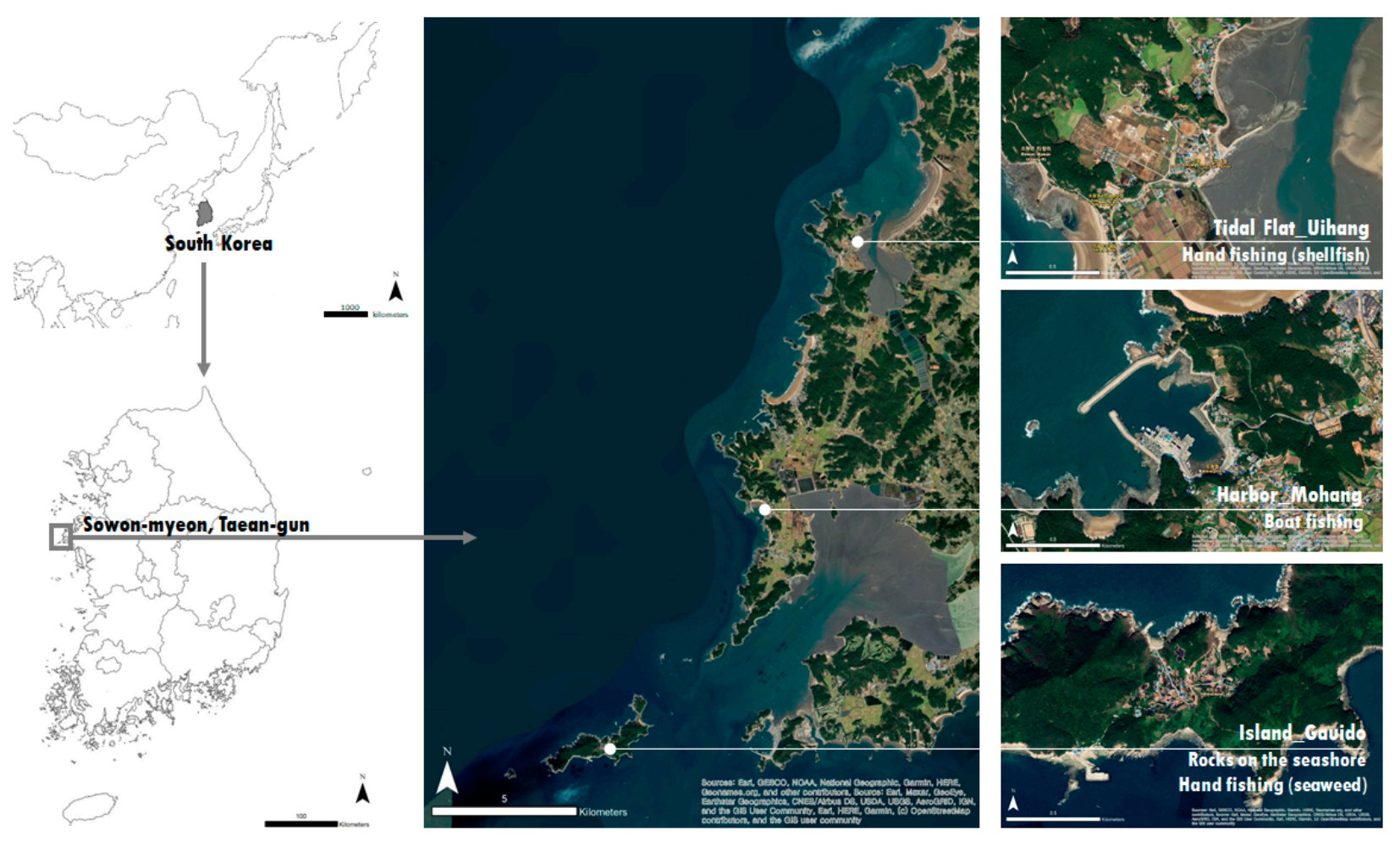

Figure 1. Geographical location of the study sites.

The steps were as follows (Figure 2): First, in-depth interviews on the damage patterns of the oil spill incident were conducted with the affected residents of the three abovementioned villages. Interviews were conducted in February 2008, immediately after the accident, after one year, and between February and March 2019. Entire interviews were recorded and their transcripts were prepared manually using a computer. Many different, but synonymous, words used by the interviewees were unified by the researcher for consistency, and the minutes of the sessions were organized.



From stakeholders

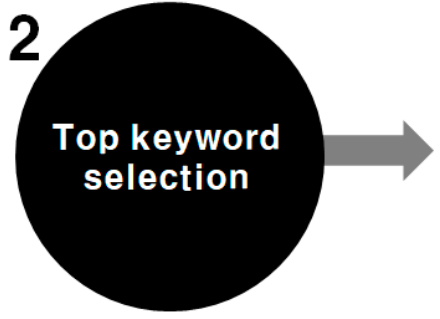

Using NetMiner

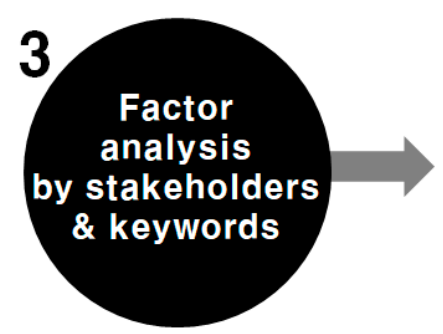

Using SPSS



With interviews

Figure 2. The text mining process.

Second, the morphemes from the summarized interview transcripts were analyzed. In this analysis, nouns that were frequently used and could have a meaning alone were determined for their main meaning in the discussion [27], and the words among the top 10\% frequently used words were selected as keywords. This step was executed with NetMiner 4.3, which can be used to conduct Korean morpheme analysis.

Third, factor analysis was conducted by converting the number of occurrences of the keywords of the stakeholders into a matrix. Factor analysis for text mining by subject was used to identify the keywords mainly used by each stakeholder and to calculate the ratio of 
keywords to the length of the entire interview. The SPSS 22.0 software was used to execute factor analysis.

Fourth, interpretation of the differences in the perception of damage by stakeholders was performed by comparatively analyzing the message characteristics for each major factor and the relevant stakeholders. By examining the actual interview sentences together, it was possible to sufficiently confirm the meaning of the discussion by each stakeholder. Based on this, the different aspects of damage according to the stakeholder, customized recovery alternatives, and the direction of recovery governance were estimated according to their interview responses.

\section{Results}

All participants provided informed consent. The Hebei Sprit oil spill accident disrupted the main industries of the region, such as fishing and tourism. Oysters, clams, sea cucumbers, and abalone farms using the natural conditions of the west coast were destroyed, and fish caught by fishing boats were also polluted. In addition, restaurants and lodging facilities near the beach were also closed. The in-depth interviews involved discussions with the local residents who lived on islands, tidal flats, and ports that were affected by such damage and were engaged in fishing and tourism. A few environmental nongovernmental organization (NGO) activists and public officials who participated in the recovery process were also included in the interviews. The major occupations of the victims affected by the Hebei Spirit oil spill, who participated in the study, are shown in Table 1.

Table 1. Major economic activities of affected residents who participated in the in-depth interviews.

\begin{tabular}{ccc}
\hline Division & $\begin{array}{c}\text { Number of } \\
\text { People }\end{array}$ & Major Occupations \\
\hline Tidal Flats & 34 & Hand fishing, bed and breakfast, raw fish restaurants, other restaurants, pastors, etc. \\
Harbor & 43 & $\begin{array}{c}\text { Boat fishing, hand fishing, lodging, agriculture, haenyeos diving, etc. } \\
\text { Boat fishing, hand fishing, bed and breakfast, agriculture, etc. }\end{array}$ \\
Island & 23 & Environmental NGO, officers, employees of disaster prevention companies, special committee, etc. \\
Others & 6 &
\end{tabular}

In-depth interviews were conducted, and frequently used nouns were extracted as keywords by analyzing the morphemes in the summarized interview transcripts. In this process, general words that lacked detailed information [27] and those that were difficult to understand individually were excluded. Consequently, the word "village" appeared 85 times, and nouns that appeared nine times (corresponding to $10 \%$ of the number of appearances of "village") or more were extracted as keywords (Table 2).

Table 2. Main keywords.

\begin{tabular}{ccccccccc}
\hline Rank & Keyword & Frequency & Rank & Keyword & Frequency & Rank & Keyword & Frequency \\
\hline 1 & Village & 85 & 14 & Sisterhood & 27 & 26 & Health \\
2 & Resident & 63 & 14 & Conflict & 27 & 28 & Expense & 14 \\
3 & Livelihood & 62 & 16 & Operation & 25 & 28 & Organization & 12 \\
4 & Disaster prevention & 54 & 17 & Opinion & 24 & 30 & Current status & 11 \\
5 & Work & 49 & 18 & Performance & 22 & 30 & Problem & 11 \\
6 & Pay & 40 & 19 & Activity & 20 & 32 & Recovery & 10 \\
6 & Change & 40 & 20 & Compensation & 18 & 32 & Fishing village & fraternity \\
8 & Damage & 38 & 20 & Issue & 18 & 35 & Fishing vessel & 10 \\
9 & Relationship & 35 & 22 & Kindness & 16 & 35 & Difficulty & Labor \\
10 & Haenyeo & 33 & 22 & Fairness & 16 & 35 & 9 \\
10 & Living expenses & 33 & 22 & Countermeasure & 16 & 33 & Public & 9 \\
13 & Samsung & 33 & 25 & Fishing & 15 & 14 & & 9
\end{tabular}


As a result of factor analyses (Table 3), 20 factors with a factor loading of 1 or higher were extracted. However, as multiple factors can cause difficulty in analysis, in this study, we extracted four factors with a factor loading of 7 or higher, below which the factor score rapidly decreases $[28,29]$. Additionally, research subjects with a significant factor loading $(p<0.01)$ of 0.4644 or higher were analyzed to investigate the distribution of stakeholders by each factor [30,31].

The four factors that were derived were as follows: Factor 1, a group that showed interest in the village community; Factor 2, a group interested in disaster prevention; Factor 3 , a group concerned with the threats to livelihood; and Factor 4, a group interested in health issues. Thus, the following different aspects of environmental pollution damage were revealed: the village community represents social relations, including conflict between residents and psychological distance after the incident; disaster prevention work indicates environmental remediation; threat to livelihood reflects economic aspects; and haenyeos highlighted physical health issues. Table 4 (Appendix A Table A1) presents more details regarding the aspects revealed.

Figure 3 presents the distribution of stakeholders by the extracted factor. In terms of gender, the results indicate that women showed more interest in Factor 1 (village community) than men, that is, they expressed more concern about the weakening of the community after the accident, including damage to the social relations between neighbors. In terms of age, residents in their 40s were highly interested in the economic aspects of Factor 3 (threat to livelihood), while those in their 60s showed interest in the environmental aspects of Factor 2 (disaster prevention). Residents older than 60 years were concerned about the social relations of Factor 1 (village community). Furthermore, residents in their 40 s were directly responsible for the education and rearing of children, and those older than 60 considered the damages to the ancient community relationships as direct damages from the incident.

Regarding the type of fishing, hand-fishing residents who shared tidal flats and coastal rocks frequently mentioned Factor 1 and Factor 3, boat fishing residents traveling to sea to catch fish spoke frequently about Factor 2, and haenyeos mentioned Factor 4 . As tidal flats used for hand fishing are a shared resource, residents engaged in hand fishing developed a strong communal relationship by working together. Although boat fisherpeople could go to less polluted sea areas on fishing vessels, hand fisherpeople working on tidal flats could not resume work until the tidal flats were cleaned. Therefore, hand fisherpeople were relatively more sensitive to the damage to social relations and threats to livelihood than other fisherpeople were.

Boat fisherpeople showed interest in Factor 2 because of their active participation in disaster prevention work immediately after the oil spill. During the early stages of the incident, the government encouraged active involvement from fishing vessels near the oil spill area, as removal of the spilled oil based solely on disaster prevention capability was difficult. As this was an emergency, the costs of participating in disaster prevention work instead of continuing fishing were not discussed in advance. Therefore, boat fisherpeople who helped during the early stages of the incident expected fair compensation of their work.

Notably, haenyeos frequently mentioned Factor 4 . As they collect seafood underwater without oxygen tanks, the majority suffered from decompression sickness even before the oil spill. Furthermore, as the haenyeos had developed a strong psychological relationship with the sea by working in deep waters without diving equipment for a long time, damage to the sea invoked a strong sense of helplessness in them. Consequently, haenyeos complained of stronger psychological stress compared with other victim groups.

In summary, women older than 60 years, and residents fishing by hand in the shared resources of tidal flats and coastal rocks were relatively more interested in the village community, that is, social relations, than other residents were. Boat fisherpeople, who stopped fishing and actively participated in disaster prevention work in the initial days of the incident, were more interested in disaster prevention. Lastly, women-only haenyeos showed greater interest in health issues. 
Table 3. Factor analysis results.

\begin{tabular}{|c|c|c|c|c|c|c|c|c|c|}
\hline \multirow{2}{*}{ Component } & \multicolumn{3}{|c|}{ Initial Eigenvalue } & \multicolumn{3}{|c|}{ Extraction Sums of Squared Loadings } & \multicolumn{3}{|c|}{ Rotation Sums of Squared Loadings } \\
\hline & Total & $\%$ of Variance & Cumulative Rate (\%) & Total & $\%$ of Variance & Cumulative Rate $(\%)$ & Total & $\%$ of Variance & Cumulative Rate (\%) \\
\hline 1 & 17.024 & 17.920 & 17.920 & 17.024 & 17.920 & 17.920 & 12.780 & 13.453 & 13.453 \\
\hline 2 & 8.940 & 9.410 & 27.330 & 8.940 & 9.410 & 27.330 & 11.491 & 12.096 & 25.549 \\
\hline 4 & 7.375 & 7.763 & 43.835 & 7.375 & 7.763 & 43.835 & 7.898 & 8.314 & 43.835 \\
\hline
\end{tabular}

Table 4. Main keywords of each factor.

\begin{tabular}{|c|c|c|c|}
\hline Factor & Keywords & Z Value & Interviews \\
\hline $\begin{array}{l}\text { Factor } 1 \\
\text { (Village community) }\end{array}$ & Village & 5.16921 & $\begin{array}{l}\text { After the oil spill incident, everyone is living on the edge. The fishing village fraternity suffered a lot. Those in } \\
\text { charge, including the village head, worked a lot. They lost their temper due to hard work. They had to travel } \\
\text { constantly between the district office and Suhyup. Since the incident, the residents do not really help each other. } \\
\text { Very stingy, nobody would care if I died. (A woman living near tidal flats.) }\end{array}$ \\
\hline $\begin{array}{c}\text { Factor } 2 \\
\text { (Disaster prevention) }\end{array}$ & $\begin{array}{c}\text { Disaster prevention } \\
\text { Work } \\
\text { Participation } \\
\text { Pay } \\
\text { Resident } \\
\text { Relationship } \\
\text { Sisterhood }\end{array}$ & $\begin{array}{l}2.28808 \\
2.06937 \\
1.30789 \\
1.09171 \\
1.08656 \\
1.07258 \\
1.00133\end{array}$ & $\begin{array}{l}\text { When the crude oil spilled, we were completely helpless. The most practical solution was to use an emulsifier } \\
\text { to push the oil down. Blue crabs are usually caught at approximately } 30 \mathrm{~m} \text { underwater. Crude oil inside their } \\
\text { body indicates that oil has been deposited. In areas with tidal differences, the amount of deposition is } \\
\text { significant. We were given labor wages for } 20 \text { days only for disaster prevention. The total amount of damage } \\
\text { and disaster prevention cost exceeded KRW } 300 \text { billion. They had to provide KRW } 300 \text { billion by reducing some } \\
\text { percentage of the disaster prevention cost. That is why they cannot pay wages now. (Men living near the port.) }\end{array}$ \\
\hline $\begin{array}{l}\text { Factor } 3 \\
\text { (Threat to livelihood) }\end{array}$ & $\begin{array}{l}\text { Resident } \\
\text { Damage } \\
\text { Livelihood } \\
\text { Issue }\end{array}$ & $\begin{array}{l}3.30339 \\
2.56108 \\
2.51501 \\
1.30707\end{array}$ & $\begin{array}{l}\text { Here, everything that comes out of the fishing ground is money; clams and oysters, they are money; } 99 \% \text { is cash. } \\
\text { But after the accident, our means of livelihood have completely disappeared. (A man living near tidal flats.) }\end{array}$ \\
\hline $\begin{array}{l}\text { Factor } 4 \\
\text { (Health) }\end{array}$ & $\begin{array}{l}\text { Haenyeo } \\
\text { Issue } \\
\text { Health } \\
\text { Disaster prevention }\end{array}$ & $\begin{array}{l}3.97013 \\
1.52811 \\
1.32 \\
1.06222\end{array}$ & $\begin{array}{l}\text { I participated in disaster prevention work. There was nothing that I can do apart from that. However, I have } \\
\text { not been paid yet. The oil smell is nauseating; it makes me vomit and dizzy. My health is failing. I keep getting } \\
\text { phlegm, and my vision has suddenly gone bad. I participated in disaster prevention work. I came here to work, } \\
\text { but since the accident occurred, I hoped to help. I got paid for the work as well. (Haenyeo living near the port.) }\end{array}$ \\
\hline
\end{tabular}


Gender



- Male $=$ Female $=$ Not answered
Age

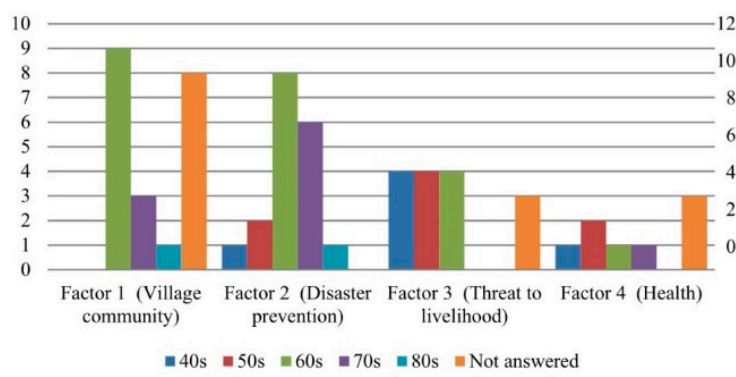

Occupation
Residence

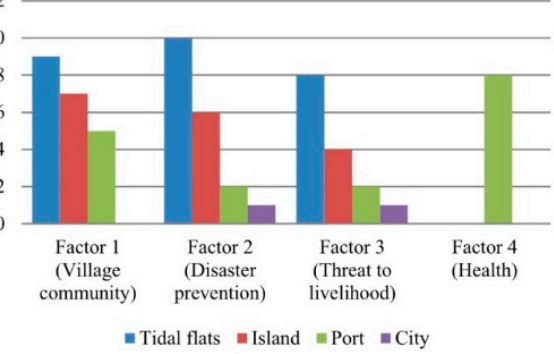



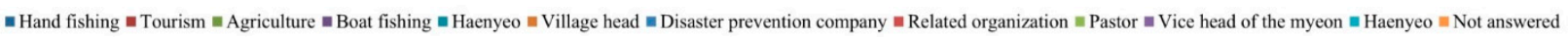

Figure 3. Distribution of stakeholders by factors.

\section{Discussion}

As environmental disasters are based on a specific environmental change, developing alternatives in response to different damage patterns that reflect regional conditions is necessary. The text mining results (Table 4 and Figure 3) indicate that the victims experienced discriminatory damage after the incident. The text mining analysis for each stakeholder revealed that the damage from the oil spill in Taean incorporated all aspects of sustainability [32,33], including the physical aspects [34,35], the social aspects of the village community, the environmental aspects of disaster prevention, and the economic aspects of the livelihood loss of residents. Additionally, haenyeos mentioned that they suffered significant damage to their physical health. Furthermore, each subject experienced different aspects of damage. Previous studies have highlighted similar results. As women are more emotional than men are, they experience more damage to the social aspects [36,37]. Boat fisherpeople working within a wide range of natural environments experience more damage to the environment $[38,39]$. Young people with relatively high costs of living experience more damage to the economic aspects [40,41]. Haenyeos working as laborers experience high levels of damage to their health [42].

Based on the results, women should be encouraged to engage in the restoration of social relations, boat fisherpeople should be encouraged to participate in environmental monitoring, young people should be provided with childcare support, and specialized fisherpeople, such as haenyeos, should be provided with medical support. Environmental disasters result in multiple major damages to victims in the community. As damage perceptions differ, conducting recovery depending on these perceptions is preferable. Efficient governance for damage recovery is possible by the proactive participation of stakeholders with each aspect of the recovery process by communicating their needs and, subsequently, helping to develop recovery initiatives [43,44].

According to the post hoc discussion on the Taean oil spill, the government had been working to restore the region by providing compensation and organizing a cooperative. However, the cooperative, which was established primarily by male leaders of the community in a top-down governance approach, could not pay the funds, because of constant 
conflict among the members. However, if governance had been established based on the mutual understanding among stakeholders and individual characters, the cooperative could have operated more efficiently. Understanding the characteristics of local victims and creating a bottom-up governance design that secures participatory inclusiveness based on mutual understanding will strengthen communication among local stakeholders [45-47].

The results of this study on how the stakeholders of Sowon-myeon, Taean, perceived damages cannot be generalized. However, this approach revealed that the damage experienced by each stakeholder is different and that recovery alternatives must be prepared by considering these differences. Therefore, a political process, which includes stakeholder investigation based on the experienced differences of the victim, is necessary. Moreover, developing governance based on these differences, and suggesting recovery alternatives based on governance, are required [48]. Future research should investigate differences in individual damage from comparatively more diverse environmental disaster cases and develop detailed processes and alternatives that reflect the needs of each subject [49].

\section{Conclusions}

In this study, we analyzed in-depth interviews with stakeholders of the Hebei Spirit oil spill in Taean to examine the differences in damages experienced by each subject. Women, boat fisherpeople, young residents, and haenyeos suffered damages in terms of the community, environmental, economic, and health aspects, respectively. The discriminatory aspects of damages are significant considerations as they suggest the need to develop governance and alternatives for environmental disaster recovery through a bottom-up approach. The results show the scope of damage recovery by confirming the impact of the damage caused by environmental disasters on human society from the biophysical environment. In addition, analyzing the responses of stakeholders to the environmental disaster can be used to initiate discussions about the scope and roles of cooperative governance in the recovery process. This methodology can be used as an important protocol that encourages inclusive governance of damage recovery in societies experiencing environmental disasters in the future. This would facilitate increased preparedness for similar potential accidents. Future studies can focus on establishing governance and alternatives for environmental disasters based on regional characteristics to provide relevant data for recovering disaster sites.

Author Contributions: Conceptualization, J.-H.L. and D.-K.K.; methodology, J.-H.L.; software, J.H.L.; formal analysis, J.-H.L.; investigation, D.-K.K.; resources, D.-K.K.; data curation, D.-K.K.; writing—original draft preparation, J.-H.L. and D.-K.K.; writing—review and editing, J.-H.L.; visualization, J.-H.L.; supervision, D.-K.K.; project administration, D.-K.K.; funding acquisition, D.-K.K. All authors have read and agreed to the published version of the manuscript.

Funding: This research was supported by a grant from basic project "A Study on the Improvement of Public Opinion Surveys for Environmental Conflict Management" funded by the Korea Environment Institute (RE2021-03).

Conflicts of Interest: The authors declare no conflict of interest. 


\section{Appendix A}

Table A1. Z values of the factors (raw data used for Table 4).

\begin{tabular}{|c|c|c|c|c|c|c|c|}
\hline Rank & Keyword & $\begin{array}{c}\text { Factor } \\
1\end{array}$ & $\begin{array}{c}\text { Factor } \\
2\end{array}$ & $\begin{array}{c}\text { Factor } \\
3\end{array}$ & $\begin{array}{c}\text { Factor } \\
4\end{array}$ & Variance & Average \\
\hline 1 & Village & 5.16921 & -0.1892 & -0.52751 & 0.15833 & 7.248309 & 1.152708 \\
\hline 2 & Resident & 0.61753 & 1.08656 & 3.30339 & -0.32883 & 2.37001 & 1.169663 \\
\hline 3 & Livelihood & 0.75057 & 0.60569 & 2.51501 & -0.89968 & 1.952443 & 0.742898 \\
\hline 4 & Disaster prevention & 0.30021 & 2.28808 & -0.18388 & 1.06222 & 1.161059 & 0.866658 \\
\hline 5 & Work & 0.15135 & 2.06937 & -0.39843 & 0.75828 & 1.1247 & 0.645143 \\
\hline 6 & Pay & 0.37716 & 1.09171 & -0.41848 & 0.02499 & 0.406907 & 0.268845 \\
\hline 7 & Change & 0.35726 & 0.80251 & 0.09829 & -0.93151 & 0.54079 & 0.081638 \\
\hline 8 & Damage & -0.27931 & -0.86216 & 2.56108 & 0.84039 & 2.26994 & 0.565 \\
\hline 9 & Relationship & -0.28297 & 1.07258 & 0.76549 & 0.89815 & 0.372846 & 0.613313 \\
\hline 10 & Haenyeo & -0.44421 & -0.23635 & -0.71485 & 3.97013 & 4.956277 & 0.64368 \\
\hline 11 & Living expenses & 0.27533 & 0.84867 & -0.59112 & -0.16188 & 0.379088 & 0.09275 \\
\hline 12 & Participation & 0.32908 & 1.30789 & -0.98623 & 0.7825 & 0.963427 & 0.35831 \\
\hline 13 & Conflict & 0.18485 & -0.41436 & 0.99699 & -0.3248 & 0.418785 & 0.11067 \\
\hline 14 & Sisterhood & -0.96714 & 1.00133 & -0.24059 & -1.64134 & 1.278789 & -0.46194 \\
\hline 15 & Opinion & -0.49417 & 0.78243 & -0.63321 & -1.13862 & 0.667855 & -0.37089 \\
\hline 16 & Operation & 0.55721 & -1.78526 & -0.28197 & -0.07756 & 0.984352 & -0.3969 \\
\hline 17 & Activity & 0.42463 & -2.09514 & 0.4056 & -0.97974 & 1.478237 & -0.56116 \\
\hline 18 & Performance & -0.57432 & 0.46518 & -0.39019 & -1.41198 & 0.592965 & -0.47783 \\
\hline 19 & Compensation & -0.54875 & -0.60467 & 0.28043 & 0.43391 & 0.295158 & -0.10977 \\
\hline 20 & Issue & -0.91402 & -0.11948 & 1.30707 & 1.52811 & 1.360582 & 0.45042 \\
\hline 21 & Kindness & 0.49456 & -0.39093 & -1.20273 & -0.33733 & 0.480645 & -0.35911 \\
\hline 22 & Fairness & -0.29856 & 0.28077 & -0.77241 & -0.59752 & 0.213392 & -0.34693 \\
\hline 23 & Fishing & 0.23968 & -1.04595 & -0.46676 & 0.17185 & 0.365235 & -0.2753 \\
\hline 24 & Income & 0.3067 & -0.75621 & -0.30437 & -0.06097 & 0.198761 & -0.20371 \\
\hline 25 & Health & -0.49957 & -0.4236 & 0.06641 & 1.32 & 0.70739 & 0.11581 \\
\hline 26 & Current status & -0.35444 & -0.49534 & -0.26648 & 0.09534 & 0.063507 & -0.25523 \\
\hline 27 & Expense & -0.09827 & -0.38245 & -0.64001 & -0.12689 & 0.064167 & -0.31191 \\
\hline 28 & Organization & 0.17483 & -1.14905 & -0.56663 & -0.14351 & 0.32776 & -0.42109 \\
\hline 29 & Problem & -0.89266 & -0.589 & 0.13528 & 0.08326 & 0.256709 & -0.31578 \\
\hline 30 & Recovery & -0.70612 & -0.32537 & -0.47877 & 0.08299 & 0.110435 & -0.35682 \\
\hline 31 & Fishing village fraternity & -0.30503 & -0.79955 & -0.1305 & -0.19915 & 0.091587 & -0.35856 \\
\hline 32 & Fishing vessel & -0.09266 & -0.92137 & -0.57247 & 0.07975 & 0.208006 & -0.37669 \\
\hline 33 & Samsung & -0.78066 & 0.95613 & -0.21771 & -1.42185 & 1.018927 & -0.36602 \\
\hline 34 & countermeasure & -0.51556 & -1.29087 & 0.40771 & -0.57252 & 0.484902 & -0.49281 \\
\hline 35 & Labor & -0.39699 & 0.32972 & -0.8697 & -0.30002 & 0.24339 & -0.30925 \\
\hline 36 & Public & -0.39699 & 0.32972 & -0.8697 & -0.30002 & 0.24339 & -0.30925 \\
\hline 37 & Difficulty & -0.86777 & -0.44202 & -0.11804 & -0.33447 & 0.099262 & -0.44058 \\
\hline
\end{tabular}




\section{Appendix B}

Table A2. Distribution of stakeholder by factors (raw data used for Figure 3).

\begin{tabular}{|c|c|c|c|c|c|c|c|c|}
\hline Factor & Gender & $\begin{array}{c}\text { Number of } \\
\text { People }\end{array}$ & Age & $\begin{array}{c}\text { Number of } \\
\text { People }\end{array}$ & Occupation & $\begin{array}{c}\text { Number of } \\
\text { People }\end{array}$ & Region & $\begin{array}{c}\text { Number of } \\
\text { People }\end{array}$ \\
\hline \multirow{6}{*}{$\begin{array}{c}\text { Factor } 1 \\
\text { (Village community) }\end{array}$} & Male & 10 & $60 \mathrm{~s}$ & 9 & Hand fishing & 8 & Tidal flats & 9 \\
\hline & Female & 10 & $70 \mathrm{~s}$ & 3 & Tourism & 3 & Island & 7 \\
\hline & & & Not answered & 8 & Boat fishing & 2 & & \\
\hline & & & & & Haenyeo & 1 & & \\
\hline & & & & & Village head & 1 & & \\
\hline & & & & & Not answered & 3 & & \\
\hline \multirow{6}{*}{$\begin{array}{c}\text { Factor } 2 \\
\text { (Disaster prevention) }\end{array}$} & Male & 13 & $60 \mathrm{~s}$ & 8 & Boat fishing & 8 & Tidal flats & 10 \\
\hline & Female & 9 & $70 \mathrm{~s}$ & 6 & Hand fishing & 5 & Island & 6 \\
\hline & & & $50 \mathrm{~s}$ & 2 & Tourism & 3 & Port & 2 \\
\hline & & & $40 \mathrm{~s}$ & 1 & \multirow{3}{*}{$\begin{array}{c}\text { Agriculture } \\
\text { Disaster prevention } \\
\text { company } \\
\text { Not answered }\end{array}$} & 1 & City & 1 \\
\hline & & & $80 \mathrm{~s}$ & 1 & & 1 & & \\
\hline & & & & & & 1 & & \\
\hline \multirow{6}{*}{$\begin{array}{l}\text { Factor } 3 \\
\text { (Threat to livelihood) }\end{array}$} & Male & 15 & $40 \mathrm{~s}$ & 4 & Hand fishing & 5 & Tidal flats & 8 \\
\hline & Female & 4 & $50 \mathrm{~s}$ & 4 & Boat fishing & 2 & Island & 4 \\
\hline & & & Not answered & 3 & Tourism & 2 & City & 1 \\
\hline & & & & & Not answered & 2 & & \\
\hline & & & & & Pastor & 2 & & \\
\hline & & & & & Vice head of the myeon & & & \\
\hline \multirow{5}{*}{$\begin{array}{l}\text { Factor } 4 \\
\text { (Health) }\end{array}$} & Male & 2 & $50 \mathrm{~s}$ & 2 & Haenyeo & 6 & Port & 8 \\
\hline & Female & 6 & $40 \mathrm{~s}$ & 1 & Tourism & 1 & & \\
\hline & & & $60 \mathrm{~s}$ & 1 & Not answered & 1 & & \\
\hline & & & $70 \mathrm{~s}$ & 1 & & & & \\
\hline & & & Not answered & 3 & & & & \\
\hline
\end{tabular}




\section{References}

1. Picou, J.S.; Marshall, B.K.; Gill, D.A. Disaster, Litigation, and the Corrosive Community. Soc. Forces 2004, 82, 1493-1522. [CrossRef]

2. Picou, J.S. Disaster recovery as translational applied sociology: Transforming chronic community distress. Humboldt. J. Soc. Relat. 2009, 32, 123-157.

3. Marshall, B.K.; Picou, J.S.; Gill, D.A. Terrorism as disaster: Selected commonalities and long-term recovery for $9 / 11$ survivors. In Terrorism and Disaster: New Threats, New Ideas; Clark, L., Ed.; Emerald Group Publishing Limited: Bingley, UK, 2003; Volume 11, pp. 73-96. [CrossRef]

4. Butter, M.E. Are Women More Vulnerable to Environmental Pollution? J. Hum. Ecol. 2006, 20, 221-226. [CrossRef]

5. Sørensen, P.B.; Thomsen, M.; Assmuth, T.; Grieger, K.D.; Baun, A. Conscious worst case definition for risk assessment, part I: A knowledge mapping approach for defining most critical risk factors in integrative risk management of chemicals and nanomaterials. Sci. Total Environ. 2010, 408, 3852-3859. [CrossRef]

6. Palinkas, L.A.; Downs, M.A.; Petterson, J.S.; Russell, J. Social, cultural, and psychological impacts of the "Exxon Valdez" Oil Spill. Hum. Organ. 1993, 53, 1-13. [CrossRef]

7. Bas, M.A.; McLean, E.V. Expecting the Unexpected: Disaster Risks and Conflict. Politi-Res. Q. 2020, 74, 421-433. [CrossRef]

8. Petit, J.; Van Der Werf, H.M.G. Perception of the environmental impacts of current and alternative modes of pig production by stakeholder groups. J. Environ. Manag. 2003, 68, 377-386. [CrossRef]

9. Sitas, N.; Reyers, B.; Cundill, G.; Prozesky, H.E.; Nel, J.L.; Esler, K.J. Fostering collaboration for knowledge and action in disaster management in South Africa. Curr. Opin. Environ. Sustain. 2016, 19, 94-102. [CrossRef]

10. Walker, A.H.; Pavia, R.; Bostrom, A.; Leschine, T.M.; Starbird, K. Communication Practices for Oil Spills: Stakeholder Engagement during Preparedness and Response. Hum. Ecol. Risk Assess. Int. J. 2014, 21, 667-690. [CrossRef]

11. Walker, A.H.; Scholz, D.; McPeek, M.; French-McCay, D.; Rowe, J.; Bock, M.; Robinson, H.; Wenning, R. Comparative risk assessment of spill response options for a deepwater oil well blowout: Part III. Stakeholder engagement. Mar. Pollut. Bull. 2018, 133, 970-983. [CrossRef]

12. Mojtahedi, M.; Oo, B.L. Stakeholders' approaches to disaster risk reduction in built environment. Disaster Prev. Manag. Int. J. 2014, 23, 356-369. [CrossRef]

13. Bruhn, J.G. The Sociology of Community Connections; Springer Science \& Business Media: Berlin/Heidelberg, Germany, 2011. [CrossRef]

14. Soares, M.D.O.; Teixeira, C.; Bezerra, L.E.A.; Paiva, S.; Tavares, T.C.L.; Garcia, T.M.; de Araújo, J.T.; Campos, C.C.; Ferreira, S.M.C.; Matthews-Cascon, H.; et al. Oil spill in South Atlantic (Brazil): Environmental and governmental disaster. Mar. Policy 2020, 115, 103879. [CrossRef]

15. Kim, D.; Yang, G.-G.; Min, S.; Koh, C.-H. Social and ecological impacts of the Hebei Spirit oil spill on the west coast of Korea: Implications for compensation and recovery. Ocean Coast. Manag. 2014, 102, 533-544. [CrossRef]

16. Choi, K.-H.; Lim, M.-H.; Ha, M.; Sohn, J.N.; Kang, J.-W.; Choi, Y.-H.; Cheong, H.-K. Psychological Vulnerability of Residents of Communities Affected by the Hebei Spirit Oil Spill. Disaster Med. Public Health Prep. 2015, 10, 51-58. [CrossRef] [PubMed]

17. Lee, J.-H. Setting the governance of a participatory ecosystem service assessment based on text mining the language of stakeholders' opinions. J. Environ. Manag. 2021, 284, 112003. [CrossRef]

18. Lee, M.; Jung, J.-Y. Pollution risk assessment of oil spill accidents in Garorim Bay of Korea. Mar. Pollut. Bull. 2015, 100, 297-303. [CrossRef]

19. Lee, C.-H.; Kang, Y.-A.; Chang, K.-J.; Kim, C.-H.; Hur, J.-I.; Kim, J.-Y.; Lee, J.-K. Acute Health Effects of the Hebei Oil Spill on the Residents of Taean, Korea. J. Prev. Med. Public Health 2010, 43, 166-173. [CrossRef]

20. Lee, H.; Lee, D.W.; Kwon, S.L.; Heo, Y.M.; Jang, S.; Kwon, B.-O.; Khim, J.S.; Kim, G.-H.; Kim, J.-J. Importance of functional diversity in assessing the recovery of the microbial community after the Hebei Spirit oil spill in Korea. Environ. Int. 2019, 128, 89-94. [CrossRef]

21. Chun, J.; Oh, J.-H.; Kim, C.-K. Oil Spill Response Policies to Bridge the Perception Gap between the Government and the Public: A Social Big Data Analysis. J. Mar. Sci. Eng. 2020, 8, 335. [CrossRef]

22. Kim, M.; Yim, U.H.; Hong, S.H.; Jung, J.-H.; Choi, H.-W.; An, J.; Won, J.; Shim, W.J. Hebei Spirit oil spill monitored on site by fluorometric detection of residual oil in coastal waters off Taean, Korea. Mar. Pollut. Bull. 2010, 60, 383-389. [CrossRef]

23. Park, H.W.; Leydesdorff, L. Decomposing social and semantic networks in emerging "big data" research. J. Inf. 2013, 7, 756-765. [CrossRef]

24. Shi, F.; Chen, L.; Han, J.; Childs, P. A Data-Driven Text Mining and Semantic Network Analysis for Design Information Retrieval. J. Mech. Des. 2017, 139, 111402. [CrossRef]

25. Lee, J.-H. Analyzing local opposition to biosphere reserve creation through semantic network analysis: The case of Baekdu mountain range, Korea. Land Use Policy 2018, 82, 61-69. [CrossRef]

26. Lim, S.; Berry, F.S.; Lee, K.-H. Stakeholders in the Same Bed with Different Dreams: Semantic Network Analysis of Issue Interpretation in Risk Policy Related to Mad Cow Disease. J. Public Adm. Res. Theory 2016, 26, 79-93. [CrossRef]

27. Luhn, H.P. A Business Intelligence System. IBM J. Res. Dev. 1958, 2, 314-319. [CrossRef] 
28. Pike, K.; Wright, P.R.S.; Wink, B.; Fletcher, S. The assessment of cultural ecosystem services in the marine environment using Q methodology. J. Coast. Conserv. 2014, 19, 667-675. [CrossRef]

29. Lee, J.-H.; Choi, H.O. Stakeholders' views on reducing financial support in government-led ecotourism areas. Ocean Coast. Manag. 2017, 144, 7-15. [CrossRef]

30. Brown, S.R. Political subjectivity: Applications of Q methodology in political science. Yale University Press. J. Mark. Res. 1982, 19, 162. [CrossRef]

31. Simpson, S.; Brown, G.; Peterson, A.; Johnstone, R. Stakeholder perspectives for coastal ecosystem services and influences on value integration in policy. Ocean Coast. Manag. 2016, 126, 9-21. [CrossRef]

32. Abrahams, D. The barriers to environmental sustainability in post-disaster settings: A case study of transitional shelter implementation in Haiti. Disasters 2014, 38, S25-S49. [CrossRef] [PubMed]

33. Dong, L.; Deng, S.; Wang, F. Some developments and new insights for environmental sustainability and disaster control of tailings dam. J. Clean. Prod. 2020, 269, 122270. [CrossRef]

34. Dorling, D.; Barford, A.; Wheeler, B. Health impacts of an environmental disaster: A polemic. Environ. Res. Lett. $2007,2,045007$. [CrossRef]

35. Beland, L.-P.; Oloomi, S. Environmental disaster, pollution and infant health: Evidence from the Deepwater Horizon oil spill. J. Environ. Econ. Manag. 2019, 98, 102265. [CrossRef]

36. Asteria, D.; Suyanti, E.; Utari, D.; Wisnu, D. Model of Environmental Communication with Gender Perspective in Resolving Environmental Conflict in Urban Area (Study on the Role of Women's Activist in Sustainable Environmental Conflict Management). Procedia Environ. Sci. 2014, 20, 553-562. [CrossRef]

37. Yerian, S.; Hennink, M.; Greene, L.E.; Kiptugen, D.; Buri, J.; Freeman, M.C. The Role of Women in Water Management and Conflict Resolution in Marsabit, Kenya. Environ. Manag. 2014, 54, 1320-1330. [CrossRef] [PubMed]

38. Sullivan, J.; Croisant, S.; Howarth, M.; Rowe, G.T.; Fernando, H.; Phillips-Savoy, A.; Jackson, D.; Prochaska, J.; Ansari, G.A.S.; Penning, T.M.; et al. Building and Maintaining a Citizen Science Network With Fishermen and Fishing Communities Post Deepwater Horizon Oil Disaster Using a CBPR Approach. New Solut. 2018, 28, 416-447. [CrossRef] [PubMed]

39. Levin, J.L.; Gilmore, K.; Carruth, A.; Nonnenmann, M.W.; Evert, W.; King, D. An Interview with Vietnamese Fishermen of Louisiana in the Wake of the Oil Spill. J. Agromed. 2010, 15, 337-342. [CrossRef]

40. Gifford, R.; Nilsson, A. Personal and social factors that influence pro-environmental concern and behaviour: A review. Int. J. Psychol. 2014, 49, 141-157. [CrossRef]

41. Nakamura, M.; Takahashi, T.; Vertinsky, I. Why Japanese Firms Choose to Certify: A Study of Managerial Responses to Environmental Issues. J. Environ. Econ. Manag. 2001, 42, 23-52. [CrossRef]

42. Kim, J.I.; Kim, M. Health Care Experiences of Korean Women Divers (Jeju Haenyeos). Qual. Health Res. 2018, 28, 756-765. [CrossRef]

43. Taeby, M.; Zhang, L. Stakeholder Value Systems on Disaster Resilience of Residential Buildings. In CCREM 2018: Construction Enterprises and Project Management; American Society of Civil Engineers: Reston, VA, USA, 2018; pp. 10-17. [CrossRef]

44. Taeby, M.; Zhang, L. Exploring Stakeholder Views on Disaster Resilience Practices of Residential Communities in South Florida. Nat. Hazards Rev. 2019, 20, 04018028. [CrossRef]

45. Bixler, R.P. From Community Forest Management to Polycentric Governance: Assessing Evidence from the Bottom Up. Soc. Nat. Resour. 2013, 27, 155-169. [CrossRef]

46. Edelenbos, J.; van Buuren, A.; Roth, D.; Winnubst, M. Stakeholder initiatives in flood risk management: Exploring the role and impact of bottom-up initiatives in three 'Room for the River' projects in the Netherlands. J. Environ. Plan. Manag. 2016, 60, 47-66. [CrossRef]

47. Guerrero, A.M.; Bodin, Ö.; McAllister, R.R.; Wilson, K.A. Achieving social-ecological fit through bottom-up collaborative governance: An empirical investigation. Ecol. Soc. 2015, 20. [CrossRef]

48. Alm, K.; Brown, M. John Rawls' Concept of the Reasonable: A Study of Stakeholder Action and Reaction between British Petroleum and the Victims of the Oil Spill in the Gulf of Mexico. J. Bus. Ethics 2020, 172, 621-637. [CrossRef]

49. Eid, M.S.; El-Adaway, I.H. Sustainable Disaster Recovery Decision-Making Support Tool: Integrating Economic Vulnerability into the Objective Functions of the Associated Stakeholders. J. Manag. Eng. 2017, 33, 04016041. [CrossRef] 